\title{
HAEMATOLOGICAL AND BIOCHEMICAL VALUES OF THE BLOOD AND BLOOD SERUM OF CAPTIVE NORTHERN WHITE RHINOCEROSES (CERATOTHERIUM SIMUM COTTONI)
}

\author{
J. VÁHALA', F. KAŠE ${ }^{2}$ AND O. A. RYDER ${ }^{3}$ \\ 'ZooVet, Stefánikova 1029, Dvưr Králové n. L., 544 01, Czech Republic \\ ${ }^{2}$ Department and Institute of Biophysics and Nuclear Medicine, King Charles University, Salmovského 3, \\ Praha 2, 12000 Czech Republic \\ ${ }^{3}$ CRES, Zoological Society of San Diego, CA 92112, USA
}

Received February 26, 1993

\begin{abstract}
Váhala J.,F. Kaše and O. A. R yder: Haematological and Biochemical Values of the Blood and Blood Serum of Captive Northern White Rhinoceroses (Ceratotherium simum cottoni). Acta vet. Brno, 63, 1994: 99-102.

Haematological and biochemical blood and blood serum values obtained from 7 northern white rhinoceroses (Ceratotherium simum cottoni) kept in the Zoological Garden at Dvưr Králové are reported. The haematological values showed significant differences between pharmacologically unaffected and immobilized animals in erythrocyte count, haematocrit, haemoglobin content and monocyte count. The haematological and biochemical values obtained in immobilized animals were compared with the data reported in the relevant literature for immobilized southern white rhinoceroses (Ceratotherium simum simum).

Adults, bloodcounts, biochemistry, white rhinoceros
\end{abstract}

There are two subspecies of the white rhinoceros (Ceratotherium simum): the southern (C. s. simum) and the northern (C. s. cottoni). In 1993 only nine animals (4 males and 5 females) of the northern subspecies were kept in captivity. Because of the great risk to which northern white rhinoceroses are exposed both in nature and captivity only few physiological data on this subspecies are available. The present short communication reports the results of haematological and biochemical examination of the blood and blood serum of this subspecies kept in the Zoological Garden at Dvưr Králové.

\section{Materials and Methods}

Eleven blood samples for haematological examination and 8 samples for biochemical examination were obtained from 7 adult clinically healthy northern white rhinoceroses ( 3 males and 4 females) during a 9 year period (1981-1989). Blood from immobilized animals (a combination of Etorphine / Acepromazine - LA Immobilon, C-Vet Ltd., Suffolk, UK) was withdrawn from the vena auricularis without previous fasting 10 to 33 minutes after administration of the drugs and from pharmacologically unaffected animals immediately after puncture of the vena auricularis. The techniques of blood withdrawal and processing were described previously (Po s písil et al. 1984, 1987).

Means ( $x$ ) and standard deviations (SD) were computed and the range of the values was assessed. The significance of the differences between pharmacologically unaffected and immobilized animals was analysed using Student's t-test.

In view of significant differences in the haematological values between pharmacologically unaffected and immobilized animals these results are reported separately for each group.

The results of haematological and biochemical examination obtained in immobilized animals were compared with the respective published data on immobilized animals of the southern subspecies.

\section{Results and Discussion}

Results of haematological and biochemical examination are presented in Tables 1 and 2. Protein profile as assessed by electrophoresis is shown in Table 3.

Comparison of the haematological values recorded for the immobilized and non-immobilized animals showed significantly higher erythrocyte count $(P<0.05)$, haematocrit $(\mathrm{P}<0.01)$ and haemoglobin content $(\mathrm{P}<0.05)$ in the former. These findings are in keeping with our previous observations made in ponies (Pos písil et al. 1986) immobilized with the same drug, thus indicating its direct effect on the course of red blood component valu- 
es. Etorphine causes increased heart rate and spleen contraction by stimulation of the sympathetic nervous system (Harth oor n 1975) and, combined with increased physical load at the onset of drug action, results in expulsion of a large quantity of red blood cells into the bloodstream and in their increased values in the peripheral blood of animals shortly after administration. No explanation can be offered for the significant difference $(P<0.05)$ in monocyte count.

The haematological values found by us in immobilized animals are similar to those reported for immobilized southern white rhinoceroses (Ha w key 1975; Jones 1979; Kock 1987; Ne ls on 1978; S e al et al. 1976) except for a higher eosinophil granulocyte value in the present study. This finding may be related to the incidence of subclinical allergic rhinitis resulting from deteriorated microclimatic conditions in the animal house during the winter period (V áhala et al. 1993).

Comparison of the blood serum biochemical values found by us in northern white rhinoceroses with those reported for immobilized animals of the southern subspecies (Jones 1979; Keep 1976; Nelson 1978; Seal et al. 1976; Van Heerden et al. 1985) revealed major differences only in some values. Thus Nelson (1978) recorded lower creatinine, urea and cholesterol values and a higher AST value. Van Heerden et al. (1985) and Seal et al. (1976) reported higher AST and alkaline phosphatase values. Higher potassium values were found in the majority of relevant studies (Jones 1979; Van Heerden et al. 1985; Keep 1976; Seal et al. 1976). Our protein profile data differ markedly only from alpha 2 fraction values reported by Van Heerden et al. (1985) who found them to be higher.

We are fully aware that no further interpretation of our results is possible considering the small number of animals and the long period of time during which the results were obtained. Unfortunately, at present it is practically impossible to obtain a larger sample of the values (only 5 captive northern white rhiceroses are available in the Zoological Garden at Dvưr Králové and 4 in San Diego Wild Animal Park; only 3 of these animals were not included in the sample). However, as this subspecies is at risk, even the modest exploratory values reported here may be of interest.

Table 1

Heematological values of the northern white rhinoceres (Ceratotherium simum cottoni)

\begin{tabular}{|c|c|c|c|c|c|c|c|c|c|}
\hline & $\mathbf{n}$ & & $\stackrel{\text { A }}{\bar{x} \pm \text { SD }}$ & Range & $\mathbf{n}$ & & $\begin{array}{c}\text { B } \\
\bar{x} \pm S D\end{array}$ & Range & $\begin{array}{c}\text { Statistical } \\
\text { difference (\%) }\end{array}$ \\
\hline Erythrocyte count $\left(10^{12} n\right)$ & 3 & 5.24 & \pm 0.35 & $4.84-5.50$ & 8 & 6.78 & \pm 1.01 & $5.66-8.32$ & 5 \\
\hline Haematocrit (1n) & 3 & 0.30 & \pm 0.02 & $0.28-0.32$ & 7 & 0.41 & \pm 0.02 & $0.38-0.44$ & 1 \\
\hline Haemoglobin content $(g / 1)$ & 3 & 140.0 & \pm 4.5 & $135-144$ & 7 & 163.7 & \pm 16.2 & 141-189 & 5 \\
\hline $\mathrm{MCH}(\mathrm{pg})$ & 3 & 26.76 & \pm 1.15 & $25.6-27.9$ & 7 & 25.05 & \pm 1.99 & $23.3-28.8$ & - \\
\hline MCHC & 3 & 0.46 & $7 \pm 0.023$ & $0.441-0.482$ & 7 & 0.396 & $6 \pm 0.052$ & $0.320-0.476$ & - \\
\hline $\operatorname{MCV}(f)$ & 3 & 57.26 & \pm 1.28 & $55.8-58.2$ & 7 & 64.04 & \pm 8.89 & $51.7-72.8$ & - \\
\hline $\begin{array}{l}\text { Leucocyte count }\left(10^{9} n\right) \\
\text { Differential count }(\%)\end{array}$ & 3 & 9.03 & \pm 1.22 & $7.7-10.1$ & 8 & 9.41 & \pm 2.04 & $7.0-13.9$ & - \\
\hline Neutrophil granulocytes & 3 & 42.6 & \pm 9.0 & $34-52$ & 7 & 43.8 & \pm 9.6 & $31-60$ & - \\
\hline Eosinophil granulocyres & 3 & 8.3 & \pm 4.6 & $3-11$ & 7 & 7.0 & \pm 3.2 & 3-13 & - \\
\hline Basophil granulocytes & 3 & 0.00 & & & 7 & 0.00 & & & - \\
\hline Monocytes & 3 & 0.3 & \pm 0.5 & $0-1$ & 7 & 3-5 & \pm 2.3 & $1-8$ & 5 \\
\hline Lymphocytes & 3 & 48.6 & \pm 5.6 & 44-55 & 7 & 45.7 & \pm 8.7 & $30-54$ & - \\
\hline
\end{tabular}


Table 2

Biochemical values of the northern white rhinoceros (Ceratotherium simum cottoni) obtained in immobilized animals

\begin{tabular}{|c|c|c|c|}
\hline & $\mathbf{n}$ & $\bar{x} \pm S D$ & Range \\
\hline Total bilirubin (umol/) & 5 & $4.08 \pm 1.47$ & $1.95-5.83$ \\
\hline Conjugated bilinubin (umoll) & 4 & $2.94 \pm 0.73$ & $2.06-3.60$ \\
\hline Total protein $(\mathrm{g} / \mathrm{l})$ & 8 & $81.5 \pm 4.9$ & $74-89$ \\
\hline Glucose (mmol/) & 7 & $5.62 \pm 0.96$ & $4.1-6.6$ \\
\hline Creatinine (umol/) & 8 & $128.7 \pm 13.1$ & $105-150$ \\
\hline Urea (mmol/) & 8 & $4.12 \pm 0.71$ & $2.7-4.8$ \\
\hline Total lipids (g/n) & 4 & $4.37 \pm 1.63$ & $2.3-6.3$ \\
\hline Triglycerides (mmol/l) & 5 & $1.07 \pm 0.88$ & $0.32-1.68$ \\
\hline Cholesterol (mmol/h) & 8 & $3.21 \pm 0.91$ & $1.7-4.5$ \\
\hline Alkaline phosphatase (ukat/l) & 8 & $0.61 \pm 0.19$ & $0.32-0.81$ \\
\hline AST (ukath) & 8 & $0.50 \pm 0.07$ & $0.41-0.63$ \\
\hline ALT (ukaV) & 8 & $0.14 \pm 0.09$ & $0.04-0.28$ \\
\hline GGT (ukat/) & 2 & $1.55 \pm 1.06$ & $0.80-2.30$ \\
\hline CK (ukat/l) & 4 & $7.97 \pm 4.00$ & $4.52-13.22$ \\
\hline LDH (uka2/1) & 1 & 7.21 & \\
\hline Magnesium (mmoln) & 8 & $0.79 \pm 0.08$ & $0.70-0.94$ \\
\hline Calcium (mmol/h) & 8 & $2.88 \pm 0.35$ & $2.46-3.37$ \\
\hline Phosphorus (mmol/n) & 8 & $1.56 \pm 0.29$ & $1.22-2.05$ \\
\hline Chlorides (mmol/h) & 8 & $101.8 \pm 5.4$ & $94-112$ \\
\hline Sodium (mmol/l) & 7 & $135.5 \pm 6.9$ & $123-143$ \\
\hline Potassium (mmol/n) & 7 & $4.28 \pm 0.42$ & $3.84-4.92$ \\
\hline Copper (umoln) & 5 & $34.62 \pm 5.66$ & $26.2-38.9$ \\
\hline Zinc (umoln) & 3 & $18.46 \pm 4.02$ & $13.9-21.5$ \\
\hline Iron (umol/n) & 6 & $43.36 \pm 14.23$ & $27.4-68.7$ \\
\hline
\end{tabular}

AST - Aspartate-aminotransferase

ALT - Alanine-aminotransferase

GGT - Gamma-glutamyluransferase

CK - Creatinkinase

LDH - Lactatdehydrogenase

Table 3

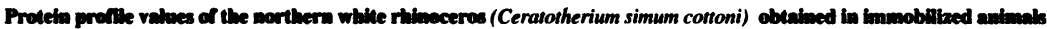

\begin{tabular}{|llcc|}
\hline & $\mathrm{n}$ & $\bar{x} \pm$ SD & Range \\
\hline Total protein $(g /)$ & 4 & $79.7 \pm 4.92$ & $74-86$ \\
Albumins $(g /)$ & 4 & $30.0 \pm 1.82$ & $28-32$ \\
Globulins & & & \\
alpha 1 $g /)$ & 4 & $1.2 \pm 0.50$ & $1-2$ \\
alpha 2 $(g /)$ & 4 & $4.0 \pm 1.41$ & $2-5$ \\
beta $(g /)$ & 4 & $17.7 \pm 1.50$ & $16-19$ \\
gamma $(g /)$ & 4 & $26.7 \pm 3.77$ & $23-32$ \\
\hline
\end{tabular}




\section{Hematologické a biochemické hodnoty krve a krevního séra nosorožce bílého severní formy (Ceratotherium simum cottoni) v zajetí}

V práci uvádíme hematologické a biochemické hodnoty krve a krevního séra získané od sedmi nosorožcủ bílých severní formy (Ceratotherium simum cottoni) ze ZOO Dvưr Králové. U hematologických hodnot jsme zjistili signifikantní rozdíly mezi farmakologicky neovlivněnými a imobilizovanými zviřaty v hodnotách počtu červených krvinek, hematokritu, obsahu hemoglobinu a počtu monocytů. Hematologické a biochemické hodnoty u imobilizovaných zvírat jsme porovnávali s literárnimi údaji pro nosorožce bílého jižní formy (Ceratotherium simum simum) získané od imobilizovaných zvírat.

\section{Гематологические и биохимические величины крови и кровяной сыворотки белого носорога северной формы (Ceratotherium simum cottoni), содержимом в неволе}

В работе приведены гематологические и биохимические величины крови и кровяной сыворотки, полученные у семи велых носорогов северной формы (Ceratotherium simum cottoni) из 300парка в Двур-Кралове. У гематологических величин была установлена существенная разница численности красных телец, гематокрита, содержания гемоглобина и числа моноцитов между животными, не находящимися под фармакологическим влиянием и иммобилизированными животными. Гематологические и биохимические величины иммобилизированных животных сопоставляли с литературными данными для белого носорога южной формы (Ceratotherium simum simum), полученные у иммобилизированных животных.

\section{References}

HARTHOORN, A. M.: The Chemical Capture of Animals. London, Bailliere Tindall, 1976, 283 p.

HAWKEY, C. M.: Comparative Mammalian Haematology - Cellular Components and Blood Coagulation in Captive Wild Animals. William Heinemann Medical Books, London, 1975.

JONES, D. M.: The husbandry and veterinary care of captive rhinoceros. Int. Zoo Yb. 19, 1979: 239-252.

KEEP, M. E.: Some Physiological Serum Normals in Free-living Wild Animal Species from Natal, South Africa. J. Zoo Anim. Med 7, 1976: 7-10.

KOCK, R.: Population and veterinary status of black rhinos in the United Kingdom. Pachyderm, 7, 1987: 29-32.

NELSON, L.: Rhinocerotidae. In: FOWLER, M. E. (eds): Zoo and Wild Animal Medicine, 2nd ed. W. B. Saunders Co., Philadelphia, 1978.

POSPIŚIL, J.-KAŠE, F.-VÁHALA, J.: Time-dependent influence of some sedating agents on basic haematological values in various artio- and perissodactylids. Comp. Biochem. Physiol. 85A, 1986: 305-308.

POSPIŠIL, J.-KAŠE, F.-VÁHALA, J.-MOUCHOVÁ, I.: Basic haematological values in antelopes - I. The Aepycerotinae and the Alcelaphinae. Comp. Biochem. Physiol. 78A, 1984: 347-351.

POSPÍSIL, J.-KAŠE, F.-ŠPÁLA, P.-VÁHALA, J.: Haematological and biochemical values in the peripheral blood of cape hunting dogs kept in the East-Bohemian Zoological Garden at Dvúr Králové nad Labem. Acta Vet. Brno, 56, 1987: 195-205.

SEAL, U. S.-BARTON, R.-MATHER, L.-GRAY, C. W.: Baseline laboratory data for the white rhinoceros (Ceratotherium simum simum). J. Zoo Anim. Med. 7, 1976: 11-16.

VÁHALA, J.-ŠPÁLA, P.-SVITALSKÝ, M.: Maintaining and breeding the Northern white rhinoceros (Ceratotherium simum cottoni) at Dvưr Králové Zoo. Int. Zoo Yb. 32, 1993: 16-20.

VAN HEERDEN, J.-KEFFEN, R. H.-DAUTH, J.-DREYER, M. J.: Blood chemical parameters in free-living white rhinoceros Ceratotherium simum. J. South Afr. Vet. Assoc. 56, 1985: 187-189. 